\title{
KAJIAN MODEL KLASIFIKASI KEGAGALAN BISNIS USAHA MIKRO KECIL DAN MENENGAH
}

\author{
Nekhasius Agus Sunarjanto ${ }^{1}$, Herlina Yoka Roida ${ }^{2}$, Cyrilius Martono ${ }^{3}$ \\ ${ }^{1}$ Jurusan Manajemen Universitas Katolik Widya Mandala Surabaya \\ Email : sunarjanto@ukwms.ac.id \\ ${ }^{2}$ Jurusan Manajemen Universitas Katolik Widya Mandala Surabaya \\ Email : yokaroida@ukwm.ac.id. \\ ${ }^{3}$ Jurusan Manajemen Universitas Katolik Widya Mandala Surabaya \\ Email : cyrillius@ukwms.ac.id
}

\begin{abstract}
ABSTRAK
problem penelitian pada UMKM adalah tidak tersedianya data laporan keuangan keuangan yang terstandard, sehingga peneliti melakukan pelatihan dan pendampingan UMKM. Hasil pelatihan dan pendampingan menghasilkan 50 responden yang memenuhi kriteria sebagai responden dalam penelitian ini. Data yang dihasilkan pada pelatihan dan pendampingan tersebut berupa laporan keuangan tahun 2016 , sehingga Penelitian ini menggunakan sampel sebanyak 50 responden yang memenuhi syarat sebagai responden. Penelitian ini mengkaji model klasifikasi kegagalan usaha UMKM di Indonesia, yang telah dihasilkan pada penelitian tahun sebelumnya model tersebut adalah, sebagai berikut : .

Ln $Y=-1.951939+4.052015 X 1+0.369247 X 7-0.743358 X 18$

$X 1=$ modal kerja $/$ total aset $X 7=$ aset lancar $/$ kewajiban lancar $X 18=$ quick aset $/$ persediaan

difinisi operasional kegagalan usaha ( Ln Y )adalah penurunan hutang lancar yang disebabkan ketidakmampuan UMKM untuk mendapatkan pinjaman modal kerja. diberi notasi 0 dan sebaliknya dberi notasi 1

Dengan data laporan keuangan pada 50 responden, dimasukkan pada persamaan diatas yang terdiri tiga variabel X1 (modal kerja / total aset) dengan koefisien 4.0520 dan signifikan 0.0314, X7 ( aset lancar / Kewajiban lancar) dengan koefisien 0.369247 dan signifikan 0.000, dan X18( quick aset / Inventory ) dengan koefisien -0.743258, , sehingga dari persamaan tersebut akan menghasilkan prediksi kegagalan atau sehat , dari hasil prediksi tersebut diuji beda dengan kondisi riil usaha , diuji dengan menggunakan model uji t berpasangan dua sisi ( paired sample t test), dengan tingkat signifikan 5\%., menghasilkan nilai $t=0.292$ dengan significant 0.771, lebih besar dari 0.05, artinya tidak ada perbedaan antara estimasi dengan aktual dengan kata lain bahwa model pada penelitian tahun pertama, dapat digunakan untuk memprediksi kegagalan usaha pada sampel penelitian tahun kedua. dari hasil penelitian ini dapat dijelaskan bahwa pada bisnis UMKM permasalahan yang sering dihadapi para pelaku UMKM adalah pada persoalan pengelolaan modal kerja. Hal ini terjadi karena ketidakmampuan manajemen dalam pengambilan keputusan serta lemahnya kendali keuangan
\end{abstract}

Kata Kunci : Model kegagalan, Prediksi kegagalan, kondisi riil Uji beda, UMKM

\section{PENDAHULUAN}

Keberadaan usaha Mikro, Kecil dan Menengah (UMKM) merupakan kondisi kehidupan ekonomi sebagian besar masyarakat Indonesia.hal ini ditunjukkan dengan data tahun 2013 yang menunjukkan bahwa sebanyak lebih dari 50 juta UMKM dengan kontribusi sebesar 56\% pada PDB. Posisi ini menempatkan usaha mikro, kecil dan menengah sebagai ujung tombak dalam pemberdayaan ekonomi rakyat, tetapi permasalahan UMKM sepertinya tidak pernah terpecahkan

Permasalahan-permasalahan UMKM yang ditemukan adalah: kurangnya akses pada sumber daya produktif, rendahnya kualitas SDM, produktivitas rendah, tingginya biaya administrasi dan transaksi, serta globalisasi ekonomi dan perdagangan bebas. Upaya yang dilakukan untuk meningkatkan peran UMKM dapat dibagi menjadi dua macam. Pertama dari sisi pelaku UMKM. Dilakukan upaya pendampingan oleh banyak organisasi pemerintah Pendampingan UMKM dilakukan untuk mengatasi persoalan rendahnya produktivitas dan kapasitas sumber daya manusia. Kedua, dari sisi kebijakan permodalan. UMKM mengalami permasalahan akses terhadap sumber permodalan. Hal ini disebabkan tidak adanya jaminan dan kemampuan untuk mengakses lembaga keuangan. Tidak adanya rekam jejak bisnis berarti pelaku usaha tidak dapat menilai keberhasilan usahanya. Oleh sebab itu, diperlukan suatu action research untuk tidak sekedar memecahkan persoalan praktik bisnis UMKM namun juga menciptakan perubahan perilaku bisnis UMKM. 
Pada penelitian tahun pertama dihasilkan model untuk memprediksi kegagalan usaha. Kegagalan usaha pada kelompok UMKM, terukur dari ketidakmampuan UMKM untuk mendapatkan pinjaman pendanaan modal kerja,atau mengalami penurunan dari hutang lancar, pendapat ini merupakan hasil kesimpulan pada saat dilakukan Fokus Group Diskusi pada kelompok UMKM dibawah bimbingan KKMB ( konsultan Keuangan Mitra Bank )

Didasarkan pada hasil penelitian tahun pertama bahwa model mampu untuk memprediksi kegagalan usaha UMKM yang berarti juga ratio keuangan dapat digunakan untuk memprediksi baik kegagalan keuangan maupun kegagalan non keuangan. Tetapi kegagalan non keuangan juga disebabkan karena faktor- factor keuangan, oleh karena itu dalam penelitian kali ini peneliti hanya memfokuskan pada penyebab kebangkrutan karena kegagalan factor keuangan

Tiga variabel yang dapat digunakan untuk memprediksi kegagalan keuangan bisnis UMKM yaitu variabel X1 (modal kerja / total aset) dengan koefisien 4.0520 dan signifikan 0.0314, X7 ( aset lancar / kewajiban lancar) dengan koefisien 0.369247 dan signifikan 0.000, dan X18( quick aset / persediaan) dengan koefisien -0.743258 dan signifikan 0.000, sedangkan untuk memprediksi kegagalan non keuangan bisnis UMKM yaitu variable X7 (aset lancar / kewajiban lancar) dengan koefisien -0.1488 dan signifikan 0.0564, dan X18( quick aset / persediaan) dengan koefisien-0.3407 dan signifikan 0.0274,

Penelitian tahun ke dua ini mengkaji model yang dihasilkan pada penelitian tahun pertama, apakah model konsisten dapat digunakan untuk memprediksi kegagalan usaha pada kelompok UMKM dengan menguji sampel pada pelaku usaha kecil menengah di surabaya, yang terdaftar atau pernah ikut pelatihan yang diselenggarakan oeh Dinas Koperasi dan UMKM Surabaya dan Dinas Perdagangan dan Perindustrian Surabaya. Karena pelaku UMKM tidak semuanya mempunyai rekam jejak keuangan yang terstandart, maka sampel pada penelitian ini terlebih dahulu diberi pelatihan dan pendampingan tentang pembuatan laporan keuangan .

\section{Tinjauan Pustaka}

Penelitian Terdahulu

Penelitian tahun pertama terinspirasi dengan model kebangkrutan Altman (1968) yang menghasilakan model sebagai berikut:

$Z=1,2 X 1+1,4 X 2+3,3 \times 3+0,6 \times 2+1,0 \times 5$

Dimana

X1 = Rasio Modal kerja / Total aset

$\mathrm{X} 2$ = Rasio Laba yang ditahan / Total aset

X3 = Rasio Laba sebelum bunga dan pajak / Total aset

$\mathrm{X} 4$ = Rasio Nilai pasar saham / Nilai buku saham

X5 = Rasio Penjualan / Total aset

Altman (1983) kemudian memperluas model di atas supaya bisa digunakan untuk perusahaan non-publik.

Model baru tersebut adalah sebagai berikut ini.

$\mathrm{Z}=0,717 \mathrm{X} 1+0,847 \mathrm{X} 2+3,107 \mathrm{X} 3+0,420 \mathrm{X} 2+0,998 \mathrm{X} 5$

Dimana

X1 = Rasio Modal kerja / Total aset

$\mathrm{X} 2$ = Rasio Laba yang ditahan / Total aset

X3 = Rasio Laba sebelum bunga dan pajak / Total aset

$\mathrm{X} 4$ = Rasio Nilai buku saham preferen dan biasa/Nilai buku total hutang

X5 = Rasio Penjualan / Total aset

Dengan mendasarkan pada teori altman, maka Penelitian pada tahun pertama Analisis data menggunakan Software Eviews 7 dan penguji hipotesis menggunakan model regresi logistik binary, dengan tingkat signifikan 5\%. menghasilkan LR (statistic) 0.000 dijelaskan pada tabel di bawah ini bahwa model menunjukan goodness of fit , artinya bahwa ratio keuangan dapat digunakan untuk memprediksi kegagalan UMKM 
Tabel 1. Hasil Analisis Data

\begin{tabular}{|l|c|c|}
\hline & $\begin{array}{c}\text { Model 1 } \\
\text { (Kegagalan keuangan) }\end{array}$ & $\begin{array}{c}\text { Model 2 } \\
\text { (kegagalan non keuangan) }\end{array}$ \\
\hline Working capital / Total asset & $4.0520^{*}$ & 1.3590 \\
\hline EBIT / Total asset & -1.5782 & 2.6953 \\
\hline Current asset / Current liabilities & $0.3692^{*}$ & $-0.1488^{*}$ \\
\hline EBT / Sales & 6.1715 & -7.870 \\
\hline Working capital / Sales & -1.9543 & 3.4217 \\
\hline Quick asset / Inventory & $-0.7432^{*}$ & $-0.3407^{*}$ \\
\hline Prob (LR statistic) & $0.0000^{*}$ & $0.0150^{*}$ \\
\hline McFadden R Squared & 0.2313 & 0.0511 \\
\hline
\end{tabular}

Note. ${ }^{*}$ Significant level 0.05

Model 1, dapat menjelaskan bahwa tiga variabel yang dapat digunakan untuk memprediksi kegagalan keuangan bisnis UKM yaitu variable X1 (modal kerja / total aset) dengan koefisien 4.0520 dan signifikan 0.0314, X7 ( aset lancar / Kewajiban lancar) dengan koefisien 0.369247 dan signifikan 0.000, dan X18( quick aset / Inventory ) dengan koefisien -0.743258 dan signifikan 0.000, hal tersebut dapat dijelaskan bahwa pada bisnis UMKM permasalahan utama adalah ketersedianya modal kerja, akses terhadap hutang lancar, pengaturan persediaan, besarnya pihutng

Model 2 hanya ada dua variabel yang memprediksi kegagalan non keuangan bisnis UKM yaitu variable X7 ( aset lancar / Kewajiban lancar) dengan koefisien -0.1488 dan signifikan 0.0564, dan X18( quick aset / Inventory ) dengan koefisien-0.3407 dan signifikan 0.0274 .

Dari hasil análisis tersebut permasalahan utama bagi UKM adalah modal kerja , diindikasikan bahwa aktiva tetap yang tidak produktif, sehingga tidak efisien dari sisi biaya , penggunaan aktiva lancar tidak sesuai dengan kebutuhan modal kerja dan manajemen persediaan yang perlu diperbaiki, dampak dari permasalahan modal kerja ini mengakibatkan pada kelancaran aliran kas

Berdasarkan hasil temuan diatas nampak bahwa kegagalan bisnis UKM sangat ditentukan oleh kemampuannya kemampuan pengelolaan aktiva lancar (rasio Quick Asset/Persediaan dan rasio Aktiva Lancar/Total Aset).

Karakteristik UMKM yang rentan atas risiko ditunjukkan lewat kemampuan menghasilkan laba sebagai prediktor kemungkinan terjadinya masalah pada UKM (Sunarjanto dan Roida, 2014). Hal ini memperkuat temuan diatas bahwa kemampuan pengelolaan aset lancar untuk menghasilkan laba bersih usaha

\section{Akuntansi dan Pembukuan UMKM}

UMKM sebaiknya menerapkan siklus akuntansi. Penerapan siklus akuntansi ini banyak memberikan manfaat bagi perusahaan dalam penyusunan pembukuan hingga laporan keuangan nantinya dapat digunakan oleh pemangku kepentingan (stakeholders) untuk pengambilan keputusan. Beberapa UKM belum memahami bentuk dan manfaat dari menerapkan siklus akuntansi sehingga usaha tersebut belum secara tepat mengukur kinerja perusahaan dan posisi keuangan yang mereka miliki. Akuntansi yang digunakan di UKM tidak jauh berbeda dengan akuntansi yang diterapkan oleh perusahaan berskala besar, hanya saja standar yang digunakan yang berbeda. Indonesia mulai 2012 mengharuskan perusahaan besar menggunakan Standar Akuntansi Keuangan besar yang mengadopsi International Financial Report Standards (IFRS) sedangkan untuk usaha berskala kecil dapat menggunakan Standar Akuntansi Keuangan - Entitas Tanpa Akuntabilitas Publik (SAK-ETAP) yang tentu saja lebih sederhana. UMKM perlu memahami konsepkonsep yang dikenal dalam akuntansi agar operasional perusahaan dapat dijalankan secara tepat dan benar. Konsep-konsep tersebut meliputi konsep entitas bisnis, konsep biaya dan konsep unit pengukuran. Konsep entitas bisnis perlu diterapkan dalam UMKM karena konsep ini membatasi data ekonomi dalam sistem akuntansi ke data yang berhubungan langsung dengan aktivitas usaha. Dengan kata lain bisnis dipandang sebagai entitas terpisah dari pemangku kepentingan lainnya. Konsep biaya adalah dasar untuk menentukan nilai tukar atau biaya. Konsep unit pengukuran berkaitan dengan pencatatan data ekonomi yang dilaporkan dengan suatu mata uang. 


\section{Pengertian Modal Kerja}

Gitman (2001) menjelaskan bahwa modal kerja adalah jumlah harta lancar yang merupakan bagian dari investasi yang bersirkulasi dari satu bentuk ke bentuk yang lain dalam suatu kegiatan bisnis. Weston dan Brigham (1986) menjelaskan bahwa manjemen modal kerja adalah investasi perusahaan dalam jangka pendek: kas, surat-surat berharga (efek), piutang, dan persediaan.

Pengertian modal kerja adalah jumlah kekayaan atau aktiva lancar, seperti kas atau uang tunai di peti kas dan di bank, piutang usaha dan persediaan bahan baku, bahan pembantu, dan barang jadi, ditambah kewajiban atau pasiva lancar, seperti hutang usaha dan pinjaman jangka pendek. Dengan demikia maka manajemen modal kerja merupakan semua kegiatan dalam rangka pengelolaan aktiva lancar dan pasiva lancar.

\section{Alternatif Metode Pengukuran Kegagalan Bisnis}

Model pengukuran kegagalan bisnis banyak berkembang selama beberapa dekade belakangan, seperti the fuzzy rule-based classification model, model logit, model CUSUM, dynamic event history analysis, cathastrophe theory, chaos theory model, multidimentional scaling, linear goal progamming, the multicriteria decision approach, rough set analysis, expected systems, dan self organizing map. Meskipun begitu, disamping model diskriminan, model yang paling populer digunakan adalah:

Pertama, Survival Analysis yaitu analisis yang mendasarkan pada asumsi bahwa gagal dan tidak gagal berdasarkan populasi yang sama antar kedua kelompak tersebut (Lane et.al., 1986; Luoma dan Laitinen, 1991; Kauffman dan Wang, 2001). Model ini juga tidak mengasumsikan adanya dikotomi pada variabel terikat (Shumway, 1999). Konsep dasar model ini adalah hazard rate sebuah usaha, akibatnya probabilitas kegagalan dimasa mendatang akan sangat tergantung pada kemampuan sebuah perusahaan untuk bertahan di masa mendatang. Dengan kata lain, pengukuran dengan menggunakan waktu secara terus menerus dirumuskan dalam Cox Proportional Hazard Model. Hazard Model mengasumsikan bahwa setiap perusahaan memiliki proporsi hazard terhadap perusahaan lain. Fokus Survival Analysis adalah menentukan faktor-faktor yang merupakan variabel bebas yang dapat mempengaruhi hazard rate dan tidak ditentukan oleh hazard rate aktual (Yang dan Temple, 2000). Selain itu juga penekanan pada nilai fungsi hazard tidak secara langsung dapat diinterpertasikan sebagai probabilitas kegagalan (Laitinen dan Kankaanpaa, 1999). Model ini sayangnya tidak dirancang untuk menentukan klasifikasi prediksi kegagalan bisnis. Kalkulasi survival times menggunakan data yang secara implisit digunakan sebagai pertimbangan titik awal proses kegagalan (Luoma dan Leitenen, 1991).

Kedua, Decision Trees merupakan model yang tidak membutuhkan persyaratan statistik yang rumit karena dapat menggunakan kualitatif data dalam pengambilan keputusan, cukup mudah digunakan karena tidak memerlukan prosedur yang rumit. Akan tetapi memiliki masalah pada spesifikasi probabilitas dan menimbulkan biaya kesalahan klasifikasi. Disamping itu juga mengasumsikan variabel terikat dikotomi dan sulit untuk diaplikasikan (Joos et.al, 1998; Frydman, 1985).

Ketiga, Neural Networks adalah model yang tidak membutuhkan asumsi yang ketat, baik digunakan pada model yang kompleks, dapat menggunakan data kualitatif, serta dapat mengatasi masalah autokorelasi. Akan tetapi model ini memiliki kelemahan yaitu sulit untuk diinterpertasikan, membutuhkan kualitas data yang baik, variabel yang digunakan haruslah terseleksi dengan baik, membutuhkan proses yang lama serta dimungkinkan adanya network yang tidak logis (Atiya, 2001; Yang et.al, 1999)

Rekonstruksi model klasifikasi kegagalan bisnis dilakukan untuk menentukan dari berbagai model yang diaplikasikan di negara berkembang, manakah yang paling sesuai untuk Indonesia. Hal ini perlu dilakukan sebagai sistem peringatan dini bagi UMKM disamping mendampingi UMKM untuk memiliki kemampuan manajerial dalam mengelola unit usahanya. 


\section{METODE PENELITIAN}

Sampel penelitian ini adalah pelaku UMKM di surabaya, yang terdaftar atau pernah ikut pelatihan yang diselenggarakan oeh Dinas Koperasi dan UMKM Surabaya dan Dinas Perdagangan dan Perindustrian Surabaya, dan memenuhi kriteria sebagai berikut :

1. Menjalankan usaha dengan skala UMKM pada tahun 2016

2. Mempunyai rekam jejak keuangan

3. Mengikuti pelatihan dan pendampingan pembuatan laporan keuangan

4. Mempunyai laporan keuangan sesuai arahan pada saat pelatihan

5. Bersedia memberikan data laporan keuangan sebagai sampel penelitian

Dengan kriteria tersebut, yang memenuhi persyaratan sebagai sampel sebesar 50 UMKM.

Metode penelitian yang digunakan adalah metode penelitian kualitatif dengan jenis action research. Tujuan action research adalah untuk memecahkan permasalahan praktis yang dihadapi dalam bisnis. Metode ini peneliti secara aktif menciptakan perubahan manajerial organisasional dan secara simultan mempelajari proses perubahan yang terjadi. Proses action research mengadopsi metode yang dikemukakan Baskerville dan Myers (dalam Myers, 2009).

1. Tahap Diagnostik

Data objek penelitian diperoleh dari karateristik perilaku anggota koperasi Agro Prima Lestari di Lamongan Jawa Timur, yang menjadi pilot project Bank Indonesia kantor wilayah Surabaya untuk klustering budidaya kedelai unggul, tetapi karena terkendala teknis maka penelitian menggunakan sampel pada UKM di Surabaya, sampel yang memenuhi syarat sebanyak 50 responden

Pre test kepada pelaku UKM untuk megukur pemahaman mereka terhadap konsep dasar kegagalan bisnis. Hal ini dilakukan dengan wawancara terstruktur mengenai topik:

a) Pemahaman membedakan aset dengan modal.

b) Pemahaman perhitungan laba usaha.

c) Pemahaman informasi keuangan.

d) Pemahaman proses bisnis usaha.

2. Tahap Pelaksanaan Tindakan

Rancangan model klasifikasi kegagalan bisnis kepada anggota koperasi. :

a) Melakukan pelatihan penyusunan pencatatan keuangan

b) Melakukan pengukuran untuk tiap objek penelitian dengan melibatkan Koperasi, pelaku

c) usaha, dan mahasiswa yang terlibat dalam survey.

d) Pendampingan dalam pembuatan pencatatan keuangan dan pengelolaan

e) modal kerja

f) Pembuatan laporan periodik: Objek penelitian diberikan kertas kerja laporan keuangan untuk merekam aktivitas yang dijalani. Secara berkala dilakukan pengamatan dan supervisi

3. Tahap Evaluasi

Analisis dampak pelatihan terhadap kegiatan usaha, dengan memasukkan data UMKM sebanyak 50 responden pada penelitian tahun pertama, yaitu

Ln Y $=-1.951939+4.052015$ X1 + 0.369247 X7 - 0.743358 X18

$\mathrm{X} 1=$ modal kerja / total aset

$\mathrm{X} 7=$ aset lancar / kewajiban lancar

$\mathrm{X} 18$ = quick aset $/$ persediaan

Aplikasi model yang dihasilkan pada penelitian tahun pertama, memasukkan data modal kerja, total asset, aktiva lancer, hutang lancer dan persediaan pada tahun 2015 maka dihasilkan prediksi pada tahun 2016, kemudian analisis dilakukan terhadap perbedaan antara hasil prediksi kegagalan usaha dengan kondisi riil usaha pada tahun 2016 


\section{Pengujian Hipotesis}

Pengujian hipotesis dilakukan dengan uji t ini bertujuan untuk menguji signifikansi perbedaan masingmasing sample . Uji t dilakukan dengan langkah-langkah sebagai berikut :

a) $\quad \mathrm{H} 0: \mathrm{b} 1, \mathrm{~b} 2, \mathrm{~b} 3=0, \quad$ berarti tidak ada perbedaan yang signifikan antara Prediksi

b) $\quad \mathrm{H} 1: \mathrm{b} 1, \mathrm{~b} 2, \mathrm{~b} 3 \neq 0$ kegagalan usaha dengan kondisi riil usaha

berarti ada perbedaan yang signifikan antara Prediksi kegagalan usaha dengan analisis kondisi riil usaha

\section{HASIL DAN PEMBAHASAN}

Analisis data menggunakan Software SPSS dan penguji hipotesis menggunakan model uji t berpasangan dua sisi ( paired sample t test ), dengan tingkat signifikan 5\%., menghasilkan driskriptif, sebagai berikut:

Tabel 2 Diskripsi data total asset

\begin{tabular}{|l|r|r|r|r|r|}
\hline & $\mathrm{N}$ & Minimum & Maximum & Mean & \multicolumn{1}{c|}{ Std. Deviation } \\
\hline total aktiva & 50 & 239800 & 1595000 & $7.15 \mathrm{E} 5$ & 255413.512 \\
Valid N (listwise) & 50 & & & & \\
\hline
\end{tabular}

Bersadarkan Tabel 2. nampak bahwa profil UMKM yang diteliti rata rata memliki total aset sebesar Rp 715.000.000, terendah sebesar Rp 239.800.000 dan tertinggi sebesar Rp 1.595.000.000 dengan demikian maka sampel penelitian adalah usaha kecil dan menengah ( UKM) mengingat berdasarkan ketentuan pemerintah UU pasal 6 No. 20 tahun 2008 tentang UMKM, skala usaha berdasar kriteria Usaha Kecil yaitu memiliki kekayaan bersih lebih dari Rp 50.000.000,00 (lima puluh juta rupiah) sampai dengan paling banyak Rp 500.000.000,00 (lima ratus juta rupiah) tidak termasuk tanah dan bangunan tempat usaha dan kriteria Usaha Menengah jika memiliki kekayaan bersih lebih dari Rp 500.000.000,00 (lima ratus juta rupiah) sampai dengan paling banyak $\mathrm{Rp} 10.000 .000 .000,00$ (sepuluh milyar rupiah) tidak termasuk tanah dan bangunan tempat usaha. Rata-rata sampel memiliki kekayaan sebesar 715.000.000 sehingga termasuk kelompok usaha Menengah.

Tabel 3. Paired samples Test

\begin{tabular}{|c|c|c|c|c|c|c|c|c|}
\hline \multicolumn{9}{|c|}{ Paired Samples Test } \\
\hline & \multicolumn{5}{|c|}{ Paired Differences } & \multirow[b]{3}{*}{$t$} & \multirow[b]{3}{*}{ df } & \multirow[b]{3}{*}{ Sig. (2-taileded) } \\
\hline & \multirow[b]{2}{*}{ Mean } & \multirow[b]{2}{*}{ Std. Deviation } & \multirow[b]{2}{*}{$\begin{array}{l}\text { Stdd Error } \\
\text { Mean }\end{array}$} & \multicolumn{2}{|c|}{$\begin{array}{l}95 \% \text { Confidence interval of the } \\
\text { Difference }\end{array}$} & & & \\
\hline & & & & Lower & Unper & & & \\
\hline Pairl ESTMASI-AKTUAL & .04000 & .96800 & .13690 & .23512 & 31512 & .292 & 49 & .771 \\
\hline
\end{tabular}

Table 3. diatas menunjukkan uji beda menggunakan uji t berpasangan ( paired samlpes $\mathrm{t}$ Test ) untuk menguji hitotesis $\mathrm{H}_{0}: \mathrm{b}_{1}, \mathrm{~b}_{2}, \mathrm{~b}_{3}=0$, berarti tidak ada perbedaan yang signifikan antara estimasi dengan aktual menghasilkan nilai $\mathrm{t}=0.292$ dengan significant 0.771 , lebih besar dari 0.05 , sehingga Ho diterima, sehingga artinya tidak ada perbedaan antara estimasi dengan aktual dengan kata lain bahwa model pada penelitian tahun pertama, dapat digunakan untuk memprediksi kegagalan usaha pada sampel penelitian tahun kedua. Berdasarkan hasil analisis statistik tersebut dapat disimpulkan bahwa pada usaha yang tergolong dalam UMKM sehingga dari analisa tersebut dapat dijelaskan bahwa pada bisnis UMKM permasalahan yang sering dihadapi para pelaku UMKM adalah pada persoalan pengelolaan modal kerja. 
Hal ini terjadi karena ketidakmampuan manajemen dalam pengambilan keputusan serta lemahnya kendali keuangan (Gitman,et all. 2012 ). Hasil análisis menunjukkan bahwa pada komponen modal kerja dalam hal ini aktiva lancar sangat penting dalam kegiatan operasionalnya dan perputaran aktiva tersebut diharapkan menghasilkan laba yang optimal sehingga profitabilitas perusahaan tercapai ( Bambang Riyanto ,1995). Kebijakan perusahaan didalam memenuhi investasi pada aktiva lancar harus diperhitungkan dengan cermat agar tidak terjadi kelebihan investasi (over invesment) yang pada akhirnya akan memperbesar biaya yang dikeluarkan untuk pengadaan dan pemeliharan aktiva tersebut, sehingga berdampak pada perolehan laba.

Perputaran modal kerja diharapkan terjadi dalam jangka waktu yang relatif pendek, sehingga modal kerja yang ditanamkan cepat kembali, (Copeland, T. and Weston, J.F.1988), dalam skala usaha mikro sering terjadi perputaran modal kerja yang relatif rendah hal ini disebabkan perputaran persediaan rendah dan perputaran piutang yang tinggi. Keputusan dalam pemenuhan kebutuhan modal kerja yang tepat merupakan syarat keberhasilan suatu usaha, disamping itu modal kerja sangat menentukan posisi likuiditas perusahaan.

Berdasarkan hasil temuan diatas nampak bahwa kegagalan bisnis UMKM sangat ditentukan oleh kemampuan pengelolaan aktiva lancar (rasio quick asset/persediaan dan rasio aktiva lancar/total aset). Karakteristik UMKM yang rentan atas risiko ditunjukkan lewat kemampuan menghasilkan laba sebagai prediktor kemungkinan terjadinya masalah pada UMKM (Sunarjanto dan Roida, 2014). Hal ini memperkuat temuan diatas bahwa kemampuan pengelolaan aset lancar akan menentukan kemampuan untuk menghasilkan laba bersih usaha.

\section{KESIMPULAN DAN SARAN KESIMPULAN}

Hasil Penelitian menunjukkan bahwa kegagalan bisnis UMKM terjadi karena tingkat likuiditas yang diukur dengan rasio-rasio aktiva lancar yang menyebabkan tidak efisien dalam pengelolaan modal kerja, maka perusahaan perlu pengendalian terhadap sumber dan penggunaan modal kerja.

Variabel yang diukur dari rasio-rasio likuiditas dan profitabilitas berpengaruh pada berbagai komponen dan faktor-faktor yang menentukan tingkat masing-masing komponen modal kerja , sehingga berdampak pada kelancaran usaha.

Penelitian pada tahun kedua menghasilkan kesimpulan bahwa model kegagalan usaha yang dibuat pada tahun pertama dapat diterapkan untuk memprediksi kegagalan usaha. Selanjutnya,

\section{SARAN}

Model prediksi kebangkrutan merupakan antisipasi dan sistim peringatan dini terhadap financial distress, sehingga model kebangkrutan yang dihasilkan dapat digunakan untuk mengevaluasi kesehatan keuangan usaha, bahkan memperbaiki kondisi sebelum sampai pada kondisi kebangkrutan. Sehingga dengan adanya prediksi mengenai kebangkrutan sangat bermanfaat bagi pihak manajemen ataupun pemerintah untuk segera memperbaiki kondisi tersebut,

Bagi pelaku usaha UMKM perlu memperhatikan pengaturan dari modal kerjanya dengan cara memperhitungkan keterikatan dana pada pada unsur unsur modal kerja, yaitu keterikatan kas, piutang , pengaturan persediaan,dan jadwal pembayaran hutang lancar

\section{Ucapan Terima kasih}

Kami sampaikan terima kasih pada LPPM Unika Widya Mandala yang telah mendanai penelitian ini, pelaku UMKM yang menjadi responden dalam penelitian ini yang dengan kemauan yang keras untuk belajar dan bersedia memberikan data ,dan Bapak Martono dan Ibu Herlina Yoka Roida sebagai Tim Peneliti yang sangat membantu pemikiran dan pelaksanaan penelitian ini serta mahasiswa sebagai asisten peneliti yang membantu pelaksanaan penelitian ini

\section{REFERENSI}

Altman, E.I. (1968), 'Financial Ratios, Determinant Analysis and The Prediction of Corporate Bankruptcy', Journal of Finance, 23(4); 589-609.

Altman, E.I. (1984), 'International Corporate Failure Model in Special Studies in Banking and Finance', Journal of Banking and Finance. 
Altman, E.I. (1993), Corporate Financial Distress, John Wiley and Sons, New York.

Altman, E.I., Baidya, T., \& Riberio-Dias, L.M., (1979), 'Assesing Potential Financing Problems of Firms in Brazil', Journal of International Business Studies.

Altman, E.I., \& Narayanan, P., (1997), 'An International Survey of Business Failure Classification Models', Financial Markets, Institutions, Instruments, 6 (2): 1-57.

Atiya, A.F., (2001), 'Bankruptcy Prediction for Credit Risk Using Neural Networks: A Survey and New Results, IEEE Transactions on Neural Networks, 12 (4), July 2001; 929-935.

Copeland, T. and Weston, J.F., (1988), Financial Theory and Corporate Finance, Addison-Wesley.

Frydman, H., Altman, E.I., and Kao, P.L., (1985), 'Introduction Recursive Partitioning for Financial Classification: The Case of financial Distress', Journal of Finance, 40 (1); 269-291.

Gitman, Lawrence J. and Zutter, Chad J. 2012. Principles of Managerial Finance, $13^{\text {th }}$ Edition, Prentice Hall. Joos, P., Vanhoof, K., Ooghe H., and Sierens, N. (1998), 'Credit Classification: A Comparation of Logit Models and Decision Trees, Proceedings Notes of The Workshop on Application of Machine Learning and Data Mining in Finance, $10^{\text {th }}$ European Conference on Machine Learning, April 24, Germany; 59-72 .

Myers, M.D ( 2009) Qualitative Research inBusiness and Management. Sage Publication: London.

Laitenen, T., and Kankaanpaa, M.m (1999), 'Comparative Analysis of Failure Prediction Methods: The Finnish Case', The European Accounting Review, 8 (1); 67-97.

Lane, W.R., Looney, S.W., and Wangley, J.W., (1986), 'An Application of Cox Proportional Hazards Model to Bank Failure', Journal of Banking and Finance, 10; 511-531.

Luoma,M., and Laitinen, E.K., (1991), 'Survival Analysis as A Tool for Company Failure Prediction', Omega International Journal of Management Science, 10 (6); 673-678.

Riyanto, B. (1995), Dasar-Dasar Pembelajaran Perusahaan, Yoyakarta: Yayasan Badan Penerbit Gadjah Mada

Sunarjanto, N.A, \& Roida, H.Y., 2013, 'Menerjemahkan Toleransi Risiko Pemilik UMKM Melalui Keputusan Penggunaan Modal yang Mengandung Risiko Bisnis dan Risiko Keuangan', Proceeding Konferensi Forum Manajemen Indonesia Ke-5 Pontianak, 23-24 Oktober 2013.

Yang Q.G., and Temple, P., (2000), 'The Hazard of Chinese Enterprises Under Reconstructing', paper presented at CEPR/ESRC Transition Economics and Chinese Economy Conference, Centre for Economic Reform and Transformation (CERT), 24/25 august 2000, Heriot-Watt, University Edinburg, 1-37.

Yang, Z.R., Platt, M.B., and Platt, H.D., (1999), 'Probabilistic Neural Networks in Bankruptcy Prediction', Journal of Business Research, 44 (2); 67-74. 